\title{
Technology of surface wastewater purification, including high-rise construction areas
}

\author{
Anna Tsyba ${ }^{1, *}$, Yury Skolubovich ${ }^{1}$ \\ ${ }^{1}$ Novosibirsk State University of Architecture and Civil Engineering, 630099, Leningradskaya str. \\ 113, Novosibirsk, Russia
}

\begin{abstract}
Despite on the improvements in the quality of high-rise construction areas and industrial wastewater treatment, the pollution of water bodies continues to increase. This is due to the organized and unorganized surface untreated sewage entry into the reservoirs. The qualitative analysis of some cities' surface sewage composition is carried out in the work. Based on the published literature review, the characteristic contamination present in surface wastewater was identified. The paper proposes a new technology for the treatment of surface sewage and presents the results of preliminary studies.
\end{abstract}

\section{Introduction}

Based on the literature review [1-5], it was revealed that one of the most important hydrosphere pollution factors are surface sewage of high-rise construction areas, which composition, in recent period, increasingly depends on the results of human activities. So far, surface sewage was considered conditionally clean and not dangerous for water bodies. However, it has now been established that surface wastewater discharged from the territories of cities and industrial enterprises is significantly polluted and can not be discharged into water bodies without preliminary treatment [5]. Therefore, an organized diversion with further surface sewage purification is an important task for improving the ecological state of water bodies. In order to determine the qualitative characteristics of the surface sewage contaminants, a theoretical analysis of some cities' surface wastewaters were carried out.

The nature and degree of surface sewage pollution of high-rise construction areas, from cities' territories and industrial enterprises, are different. Their qualitative and quantitative characteristics depend on the level of a city municipal improvement, sanitary state of water catch basin area, surface atmosphere, as well as hydrometeorological parameters of precipitation: intensity and duration of rains, period of dry weather, and the intensity of snow melting process. The amount of surface runoffs pollutants depends on the population density, level of landscaping, type of surface cover, frequency of streets cleaning, traffic intensity, presence of industrial enterprises and amount of atmosphere emissions . [6].

\footnotetext{
* Corresponding author: michmacha@mail.ru
} 
The recommendation on the system calculation for collecting, diversion and cleaning of surface runoff from residential areas showed that the main sources of surface runoff pollution occurring in urban areas and industrial sites are as a rule of:

- road surface wastes, products of road paving;

- products of soil surface erosion; emissions of suspended substances in the atmosphere by industrial enterprises, motor transport, heating systems;

- spills of oil products on the pavement surface; loss of bulk and liquid products, raw materials, semi-finished products;

-places for domestic garbage.

The highest level of surface runoff pollution is observed in the territories of large shopping centers, highways with intensive traffic, areas of industrial and trucking enterprises, and unorganized construction sites.

Pollution of surface runoff can be classified as follows [6-8]:

- organic and mineral impurities of natural origin, formed as a result of gases absorption from the atmosphere and erosion of the soil (sand particles, clay humus);

- substances of technogenic origin (oil products, synthetic surfactants, heavy metal compounds, etc.);

- bacterial contamination entering the drainage system with unsatisfactory sanitary and technical condition of the territories and sewerage networks.

Surface runoff from industrial sites has, as a rule, a more complex composition, and the concentration of pollution in it is higher than in urban runoff. The content of suspended solids can reach tens of grams per liter. High biochemical oxygen demand values are observed in the surface runoff from light and food industry enterprises, meat processing plants, tanneries and dairies, textile enterprises. From the ash dumps of the HPS, precipitation is washed out by phenols, which content in the surface runoff can reach hundreds of milligrams per liter. The bottom sediments forming in the zones of surface runoff discharges become secondary sources of water pollution by heavy metal compounds, which determine the increased background content in water of the corresponding ingredients. Forming hardly soluble complexes, heavy metal compounds practically do not linger on traditional treatment facilities of water pipes [9].

The oil products present in the surface runoff, getting into the water bodies, significantly affect the oxygen regime. At high concentrations of suspended solids, partial precipitation occurs in the discharge section of surface wastewater and downstream. That leads to water bodies' siltation and prevents the normal course of biological processes at the bottom of the reservoir. The organic part of suspended solids is oxidized by dissolved oxygen in water.

Present in the surface runoff oil products, when ingested, significantly affect the oxygen regime. First, oxidizing, they consume dissolved oxygen in the water and, secondly, a great damage from oil products is applied to microorganisms and fish farming. Fish are very sensitive to changes in the water chemical composition and the presence of petroleum products, especially, during the embryonic period. Oil products, getting into a reservoir, also lead to plankton death, an important component of fish fodder base. The presence of petroleum products in reservoirs and bottom sediments leads to the decrease of dissolved oxygen and microorganisms in water, as a result the processes of natural self-purification of water bodies are sharply slowed down [7].

Based on the theoretical analysis of the surface sewage composition in some Russian cities, their characteristics were determined (Table 1), which allowed giving some average quantitative characteristic of the surface urban runoff contamination. The content of suspended solids is 1.5-6 g / 1 , BOD5 40-120 mg O2 / 1, COD 400-750 mg O2 / L, petroleum products $-20-25 \mathrm{mg} / 1$. Contain of heavy metal compounds of asbestos fibers in the surface runoff from urban areas can be found with great consistency. The amount of 
surface runoff is 10-100 times higher than in domestic wastewater. The amount of urban run-offs pollution exceeds the MAC values for suspended substances, BOD, petroleum products, phosphates and heavy metals. Surface runoff accounts for approximately $75 \%$ of suspended solids, $20 \%$ of organic substances (BOD), $68 \%$ of petroleum products, and $65 \%$ of heavy metals entering reservoirs [2].

Table 1. Characteristics of the surface runoff quality of some Russian cities' territories

\begin{tabular}{|l|l|l|l|l|l|}
\hline \multicolumn{1}{|c|}{ Indexes } & $\begin{array}{c}\text { Samara } \\
{[8]}\end{array}$ & $\begin{array}{c}\text { Saint } \\
\text { Petersburg [1] }\end{array}$ & $\begin{array}{l}\text { Volgograd } \\
{[1]}\end{array}$ & $\begin{array}{c}\text { nternational } \\
\text { Review [14] }\end{array}$ & MPC p.x.[2] \\
\hline $\begin{array}{l}\text { Suspended } \\
\text { substances, mg / 1 }\end{array}$ & $50-1450$ & $300-600$ & $420-1250$ & 150 & $\begin{array}{l}+0,25 \\
\text { background }\end{array}$ \\
\hline Iron total, mg / & $0,03-10,7$ & $2-12$ & - & - & 0,1 \\
\hline BOD, mg / 1 & $5,2-316$ & $20-50$ (BOD 5$)$ & $\begin{array}{l}39,2- \\
118,5\end{array}$ & - & 3 \\
\hline $\begin{array}{l}\text { Petroleum } \\
\text { products, mg / 1 }\end{array}$ & $0,125-475$ & $7-12$ & $0,75-3$ & - & 0,05 \\
\hline Sulphates, mg / 1 & $63,4-792$ & - & $126,8-216$ & - & 100 \\
\hline $\begin{array}{l}\text { Nitrogen } \\
\text { ammonium, mg / 1 }\end{array}$ & $3,8-11,2$ & $8-10$ & $0,45-2,08$ & 2,10 & 0,39 \\
\hline pH & $7-8$ & - & $7,41-7$, & - & $6,5-8,5$ \\
\hline Zinc, mg / 1 & $0-0,035$ & - & 0,039 & 0,25 & 0,01 \\
\hline Copper, mg / 1 & $0-0,58$ & - & 0,22 & - & 0,001 \\
\hline Aluminum, mg / 1 & $0-0,1$ & $1-6$ & - & - & 0,04 \\
\hline Cadmium, mg / 1 & $0-0,05$ & - & - & 0,0045 & 0,005 \\
\hline Chromium, mg / 1 & $0-0,065$ & - & - & - & 0,001 \\
\hline Nickel, mg / 1 & 0 & - & - & 0,03 & 0,01 \\
\hline
\end{tabular}

\section{Method}

In order to purify the surface wastewater, the following cleaning methods are used: mechanical, chemical, physicochemical and biological.

Mechanical cleaning of surface sewage is carried out by means of: sedimentation, filtration, flotation. The classical scheme of sewage treatment plants includes grids, sand catchers, settling tanks. Filters (sand, coalescent, sorption) and biological ponds are used for post-treatment of surface sewage from oil products. Flotators can be used for purification of industrial surface wastewater with high concentrations of petroleum products instead of sedimentation tanks.

The biological method of cleaning surface wastewater is based on the use of aerobic microorganisms' vital activity. Biological purification is advisable to use for the removal of dissolved organic compounds (COD and BOD) from the surface runoff, as well as to reduce the content of synthetic surfactants, nitrogen and phosphorus compounds.

New wastewater treatment technology was developed using a new filtering facility of the reactor-clarifier in NGASU (Sibstrin), in order to improve the efficiency and the facilities for wastewater treatment development (Fig. 2) [10]. According to the technological scheme, averaging of sewage in the settler-regulator is assumed. Then the wastewater gets the mixer-air separator, where it is freed from air bubbles and mixed with the flocculant. Further, the wastewater is purified in the clarifier reactors.

Purification of water in the clarifier reactor occurs in the bottom upwards direction with the rate of the upward flow 1.5 times higher than the filtration rate in conventional contact clarifiers under normal operation conditions [11]. At the same time, the load increased by $10 \%$, this was necessary for the grains separation and its stagnant zones elimination. The loading grains were in a stationary state relative to each other. Grains separation leads to 
their working surface increasing, the loading layer porosity and decreasing the hydraulic resistance to the motion of the clarified liquid in it. As contact loading, quartz sand or any other fine-grained material that meets the requirements for chemical resistance and mechanical strength is used. As a result, the clarifier reactor combines advantages of granular filters and clarifiers with suspended sediment, has high productivity, reliable operation and low operating cost [12-15].

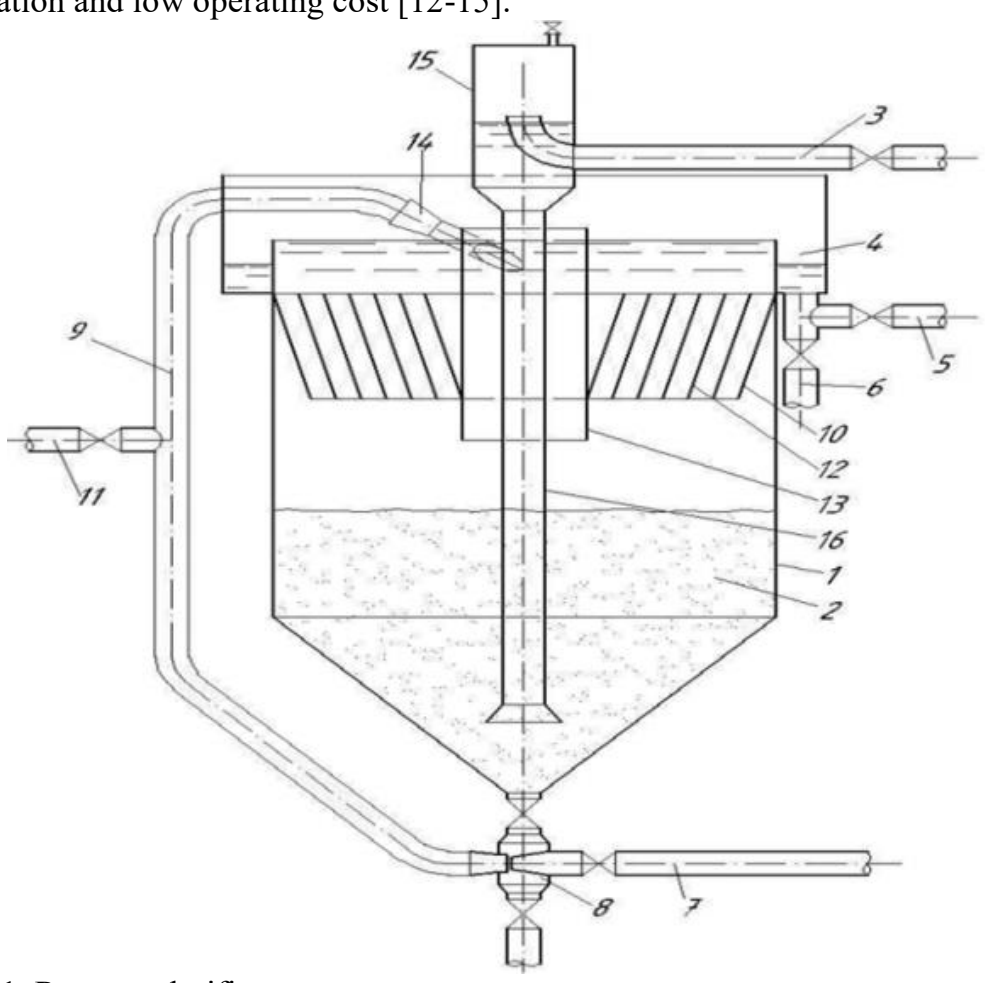

Fig. 1. Reactor-clarifier

1 - housing; 2 - contact loading; 3 - pipeline of source water; 4 - collecting trough; 5 - the pipeline of clarified water; 6.7 - pipelines for tapping and supplying wash water; 8 hydroelevator; 9 - pulp transport pipeline; 10 - conical diaphragm; 11 - pulp discharge pipeline; 12 - thin-layer module; 13 - semisubmissive cylinder; 14 - air ejector; 15 - air separator; 16 - lower distribution tube.

\section{Results}

In order to confirm the efficiency of wastewater treatment, a technological scheme for cleaning with an experimental model of the clarifier reactor loaded with burnt fuels with 0.8-1.25 mm fractional composition and a height of the loading layer of $0.96 \mathrm{~m}$ was collected in the NSASU (Sibstrin) laboratory. Laboratory tests of the reactor-clarifier on surface sewage waters of Kemerovo region were carried out. The characteristics of laboratory tests are presented in Table 2.

During the experiment, the ascending flow rate was $8.6 \mathrm{~m} / \mathrm{h}$. High degree of water purification by suspended matter was observed up to $10 \mathrm{mg} / 1$ at the exit from the plant for 10 hours period, the field of manifestation of breakthroughs with values up to $30 \mathrm{mg} / 1$ was stopped. The results of the studies are summarized in Table 2. 
Table 2 Investigation results of the reactor-clarifier efficiency

\begin{tabular}{|l|l|l|c|c|}
\hline $\mathrm{N}$ & Indexes & $\begin{array}{l}\text { Unit. } \\
\text { measurements }\end{array}$ & $\begin{array}{l}\text { Contamination } \\
\text { values in } \\
\text { source water }\end{array}$ & $\begin{array}{l}\text { The values of } \\
\text { contamination in } \\
\text { purified water }\end{array}$ \\
\hline 1 & chromaticity & degrees & 186 & 5,0 \\
\hline 2 & feculence & $\begin{array}{l}\mathrm{EFM} \\
\mathrm{mg} / \mathrm{dm}^{3}\end{array}$ & $\begin{array}{c}386,0 \\
224\end{array}$ & 1,0 \\
\hline 3 & $\mathrm{pH}$ & $\mathrm{unit} . \mathrm{pH}$ & 7,3 & 7,6 \\
\hline 4 & $\begin{array}{l}\text { Oxidizing property, } \\
\text { permanganate }\end{array}$ & $\mathrm{mgO} / \mathrm{dm}^{3}$ & 5,0 & 3,0 \\
\hline 5 & Alkalinity & $\mathrm{mmol} / \mathrm{dm}^{3}$ & 6,8 & 7,4 \\
\hline 6 & Rigidity & $\mathrm{F}$ & 8,3 & 7,5 \\
\hline 7 & Calcium & $\mathrm{mg} / \mathrm{dm}^{3}$ & 50,1 & 42 \\
\hline 8 & Magnesium & $\mathrm{mg} / \mathrm{dm}^{3}$ & 70,5 & 65,7 \\
\hline 9 & Ammonium ion & $\mathrm{mg} / \mathrm{dm}^{3}$ & 0,4 & 0,2 \\
\hline 10 & Ammonium ion & $\mathrm{mg} / \mathrm{dm}^{3}$ & 0,05 & 0,04 \\
\hline 11 & Ammonium ion & $\mathrm{mg} / \mathrm{dm}^{3}$ & 2,1 & 1,5 \\
\hline 12 & Iron & $\mathrm{mg} / \mathrm{dm}^{3}$ & 0,2 & 0,1 \\
\hline 13 & Manganese & $\mathrm{mg} / \mathrm{dm}^{3}$ & 0,1 & 0,1 \\
\hline
\end{tabular}

Preliminary results of investigations in the purification technological scheme of clarifier reactor using showed a high degree of water clarification.

On the basis of the analysis, it can be proclaimed that surface wastewater causes significant harm to water bodies, polluting them with suspended substances, petroleum products, heavy metals and require cleaning. Technological scheme for the surface wastewater purification was adopted on the basis of carried out research

\section{References}

1. V.I. Kichigin, P.G. Bykova, Water supply and sanitary engineering. Issue. 1. 28-32 (2002)

2. M.A. Gridneva, Improvement of the disposal and purification of surface sewage from urban areas: the author's abstract. PhD Thesis, Samara. (2004)

3. A.G. Melekhin, I.S. Shchukin, Construction and architecture. 1, 122-132 (2012)

4. I.N. Sukhanov, Analysis of ecological safety of the city of Novosibirsk. Novosibirsk, 215 (2012)

5. A.A.Volchek, I.V. Bul'skaya, Bulletin of the Brest State Technical University. Issue 2, 41-43 (2012)

6. M.I. Alekseev, A.M. Kurganov, The organization of surface (rain and thawed) drainage from urbanized territories. Tutorial. (Moscow, Publishing House of the ASV, 2000)

7. Recommendations on the calculation of systems for collecting, diversion and cleaning of surface runoff from residential areas, sites of enterprises and determining the conditions for its release into water bodies, Moscow, JSC "NII VODGO" (2014)

8. V.S. Dikarevsky, A.M. Kurganov, A.P. Nechaev, M.I. Alekseev Removal and cleaning of surface sewage. Tutorial. L . (Stroiizdat, 1990) 
9. L.P. Ignatieva, Sanitary protection of water objects: textbook, MO Potapova; Ministry of Health. Russia, Department of Communal Hygiene and Hygiene of Children and Adolescents. Irkutsk. IGMU (2016)

10. E.L. Voitov, Yu.L. Skolubovich, Patent 23070754, the Russian Federation, MKI C02F 1/52. The device for water treatment, 27. Publ. 27.09.2007

11. H.P. Duncan, Urban Stormwater Quality: A Statistical Overview, Cooperative Research Center for Catchment Hydrology, Melbourne, Australia (1999)

12. E.L. Voitov, Preparation of drinking water from surface sources with increased natural and anthropogenic pollution, Novosibirsk. NGASU (Sibstrin), (2010)

13. A.E. Krutkov, E.L. Voitov, Yu.L. Skulubovich, A.A. Tsyba, Efficiency of wastewater treatment of coal industry enterprises, Novosibirsk State University of Architecture and Civil Engineering (Sibstrin). Issue 1 (64), (2017)

14. Yu.L. Skolubovich, E.L. Voitov, A.E. Krutkov, Increasing the efficiency of wastewater treatment in coal mining enterprises, News of Higher Educational Establishments. Construction works. 4 (2015)

15. Yu.L. Skolubovich, E.L. Voitov, A.Yu. Skolubovich, Preparation of drinking water from surface sources in ecologically unfavorable areas, the Academy of Sciences' Reports of the Higher School, Russia, Novosibirsk State Technical University, Issue 1 (2008) 